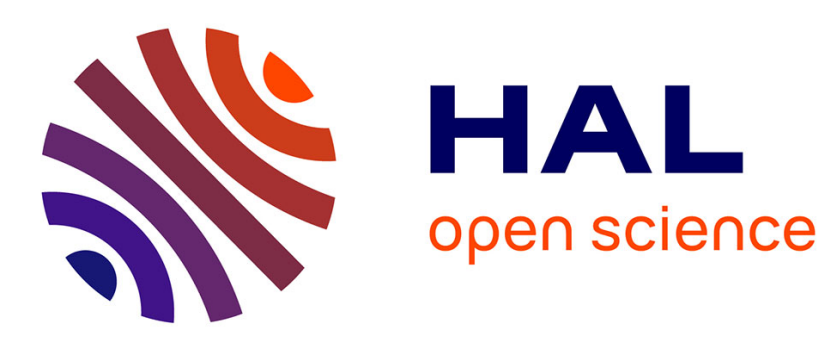

\title{
Critical evaluation of the thermodynamic properties of the cadmium-antimony system
}

\author{
C. Bernard, I. Ansara
}

\section{To cite this version:}

C. Bernard, I. Ansara. Critical evaluation of the thermodynamic properties of the cadmium-antimony system. [Research Report] LTPCM. 1974, 17 p. hal-01364055

\section{HAL Id: hal-01364055 \\ https://hal.science/hal-01364055}

Submitted on 12 Sep 2016

HAL is a multi-disciplinary open access archive for the deposit and dissemination of scientific research documents, whether they are published or not. The documents may come from teaching and research institutions in France or abroad, or from public or private research centers.
L'archive ouverte pluridisciplinaire HAL, est destinée au dépôt et à la diffusion de documents scientifiques de niveau recherche, publiés ou non, émanant des établissements d'enseignement et de recherche français ou étrangers, des laboratoires publics ou privés. 


\section{LABORATOIRE DE THERMODYNAMIQUE}

\section{ET PHYSICO-CHIMIE METALLURGIQUES}
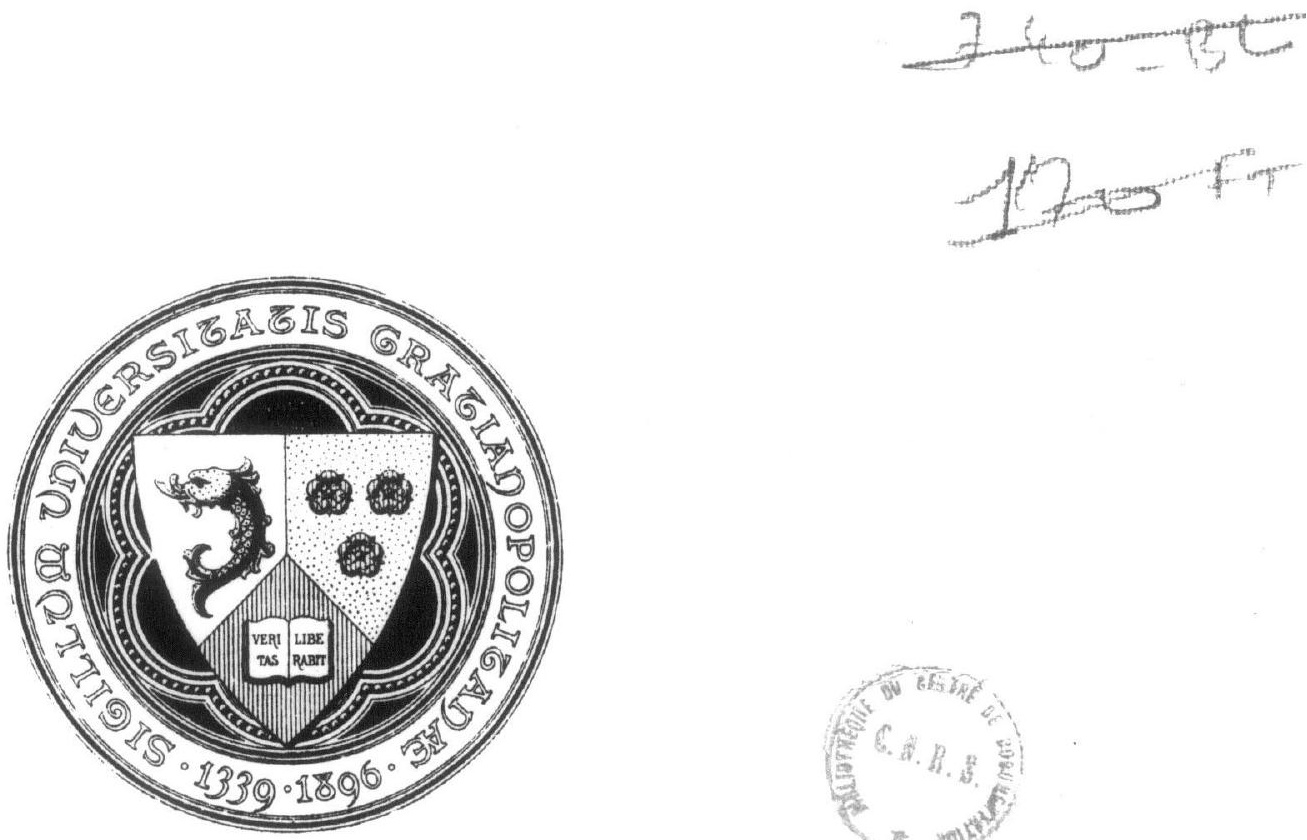

\section{$1 \rightarrow$ CRitical evaluation of the thermodynamic properties}

OF THE CADMIUM-ANTIMONY SYSTEM

by

C. BERNARD and I. ANSARA

\section{REFERENCE: RAPPORT LTPCM-1974-TM-02}


CRITICAL EVALUATION OF THE THERMODYNAMIC PROPERTIES OF THE CADMIUM-ANTIMONY SYSTEM

by

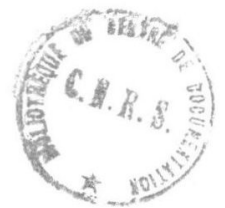

C. BERNARD and I. ANSARA 


\section{P}

The phase diagram reported by HANSEN ${ }^{(1)}$ ELJIOTT $^{(2)}$ and SHUNK (3) indicate a stable liquidus with CdSb phase formation exhibiting a small range of non-stoichiometry, and metastable compounds $\mathrm{Cd}_{3} \mathrm{Sb}_{2}$ and $\mathrm{Cd}_{4} \mathrm{Sb}_{3}$. The existence of these metastable compounds has recently been confirmed by HAYER ${ }^{(4)}$ who redetermined the phase diagram by differential thermal analysis.

The following lists presents the different thermodynamic measurements mide on the CdSb compound and the liquid alloys.

\section{Cd $\underline{\text { Sb }}$ compound}

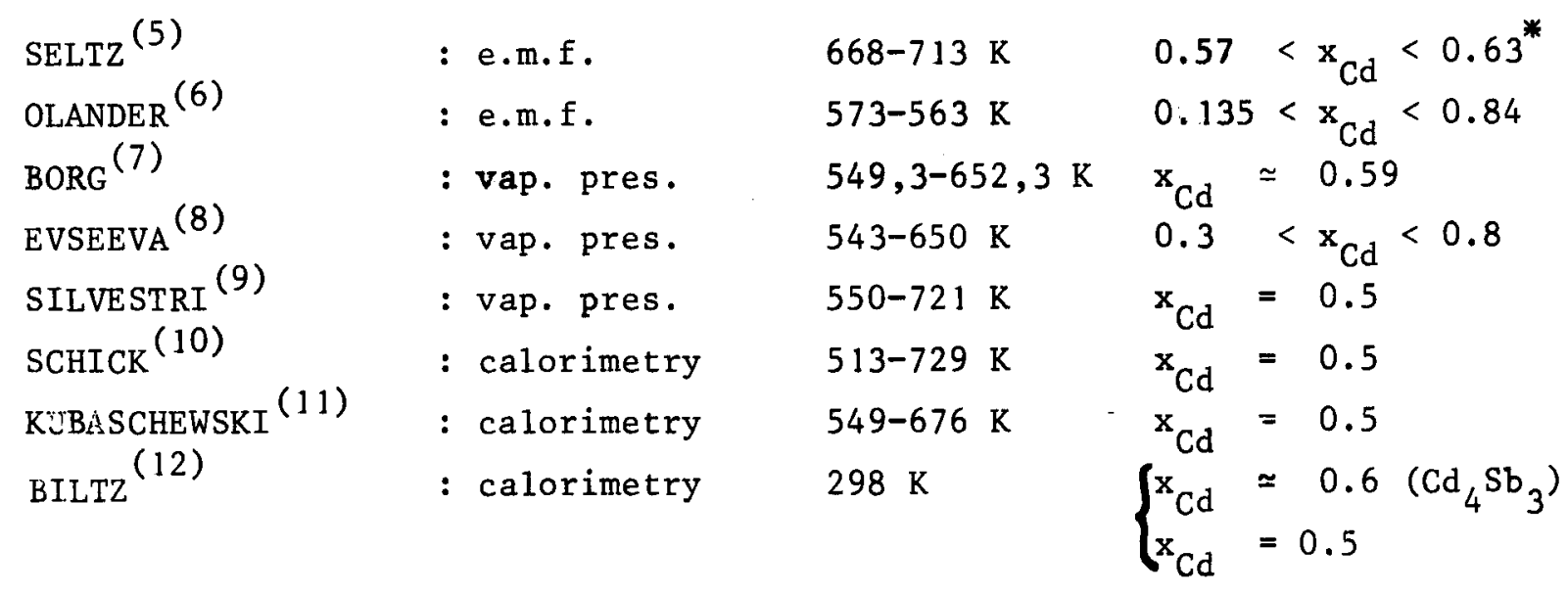

* The symbols are described in appendix $I$. 


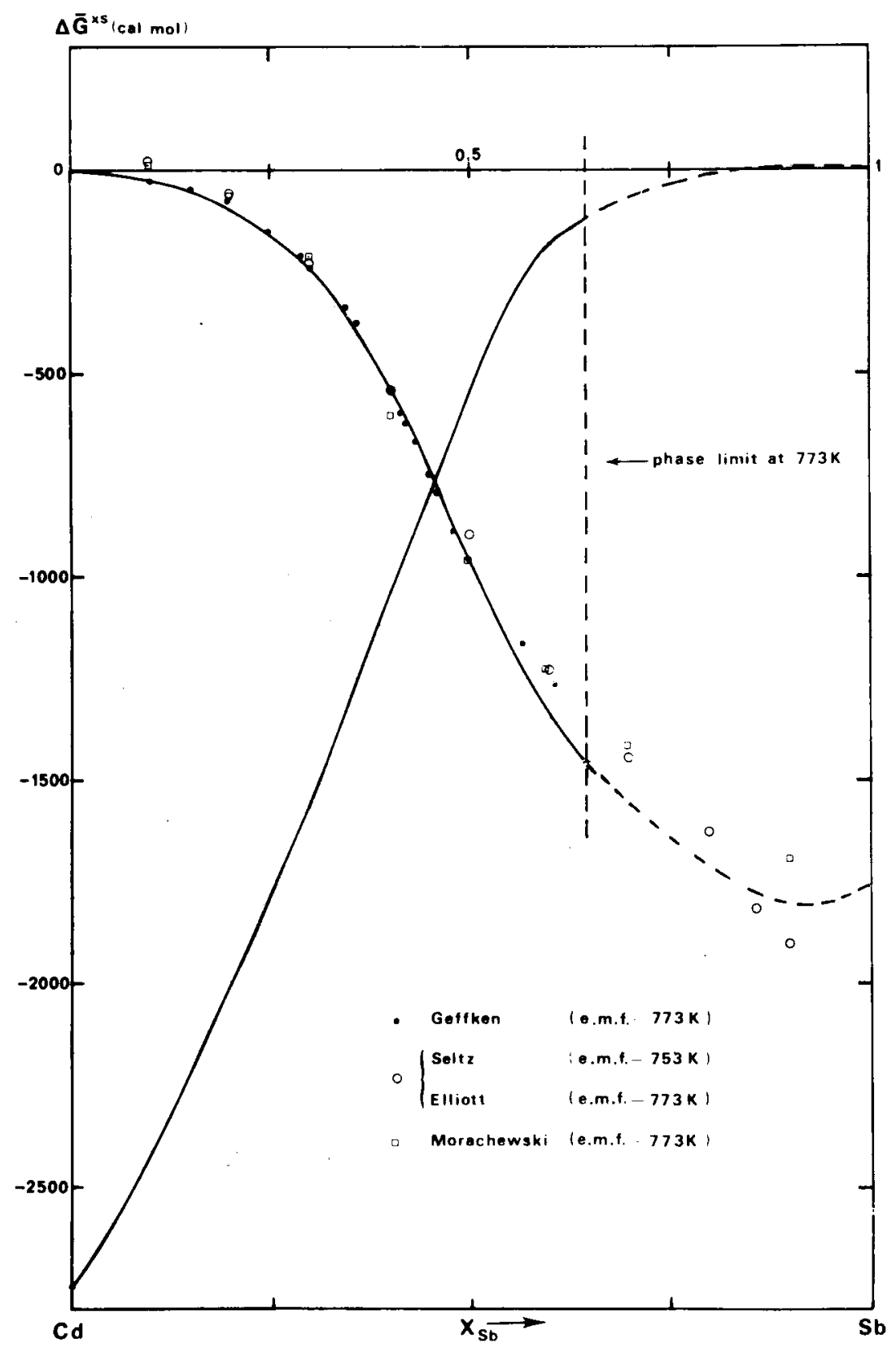

FIGURE I 


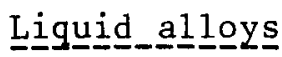

Heats of mixing

$\begin{array}{llrl}\operatorname{KAWAKAMI}^{(13)} & : \text { calorimetry } & 1073 \mathrm{~K} & 0.256<\mathrm{x}_{\mathrm{Cd}}<0.81 \\ \text { WITTIG }^{(14)} & : \text { calorimetry } & 913 \mathrm{~K} & 0.08<\mathrm{x}_{\mathrm{Cd}}<0.9017 \\ \operatorname{SCHEIL}^{(15)} & : \text { calorimetry } & 738 \mathrm{~K} & 0.419<\mathrm{x}_{\mathrm{Cd}}<0.907 \\ \text { CASTANET }^{(16)} & : \text { calorimetry } & 705-740 \mathrm{~K} & 0.325<\mathrm{x}_{\mathrm{Cd}}<0.975\end{array}$

Heat content

KUBASCHEWSKI $^{(11)}$ : calorimetry $\quad 753-875 \mathrm{~K} \quad \mathrm{x}_{\mathrm{Cd}}=0.5$

Specific heat

$\operatorname{SCHICK}^{(10)} \quad:$ calorimetry $\quad 575-911 \mathrm{~K} \quad 0 \leqslant \mathrm{x}_{\mathrm{Cd}} \leqslant 1$

\section{Partial free energies}

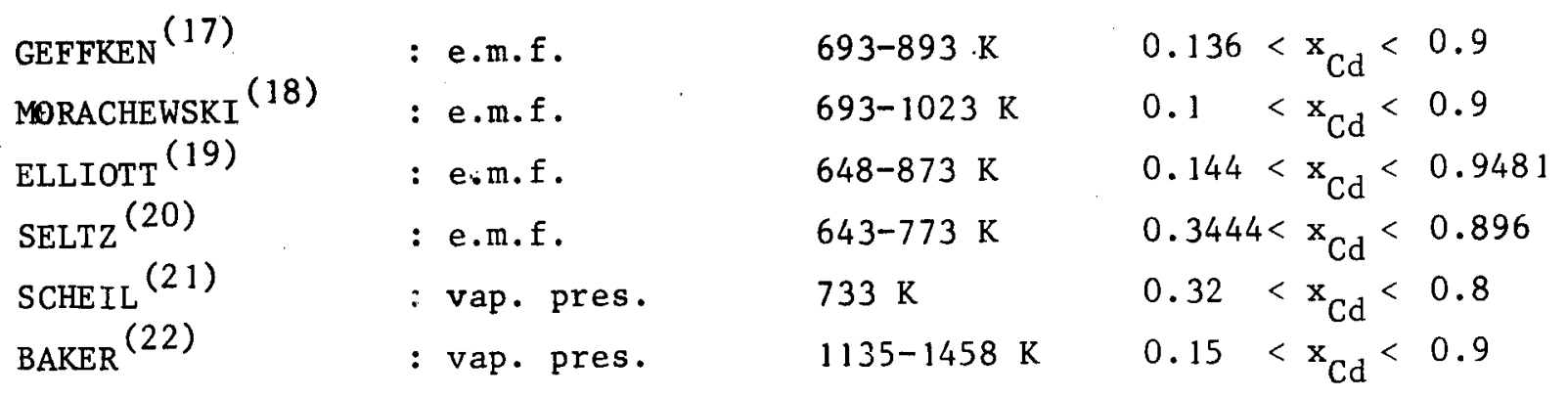

\section{CRIIIICEAL_EVALLUATIION :}

\section{A) LIQUID ALLOYS :}

\section{1 - Partíial fré}

Figure 1 presents the experimental results of $\Delta \overline{\mathrm{G}} \mathrm{Cd}$ obtained at 753 and for $773 \mathrm{~K}$ by SELTZ, GEFFKEN, ELLIOTT, MORACHETiSKI. These differents measurements agree very well; Other measurements by SCHEIL which are about $350 \mathrm{cal} / \mathrm{mol}^{*}$ less negative in the composition range 0.4-0.6 values taken from a graphical plot) have not been plotted. The selected values agree within $\pm 50 \mathrm{cal} / \mathrm{mol}$.

* mole refers to $\mathrm{Cd}_{\mathrm{x}} \mathrm{Sb}_{1-\mathrm{x}}$ 


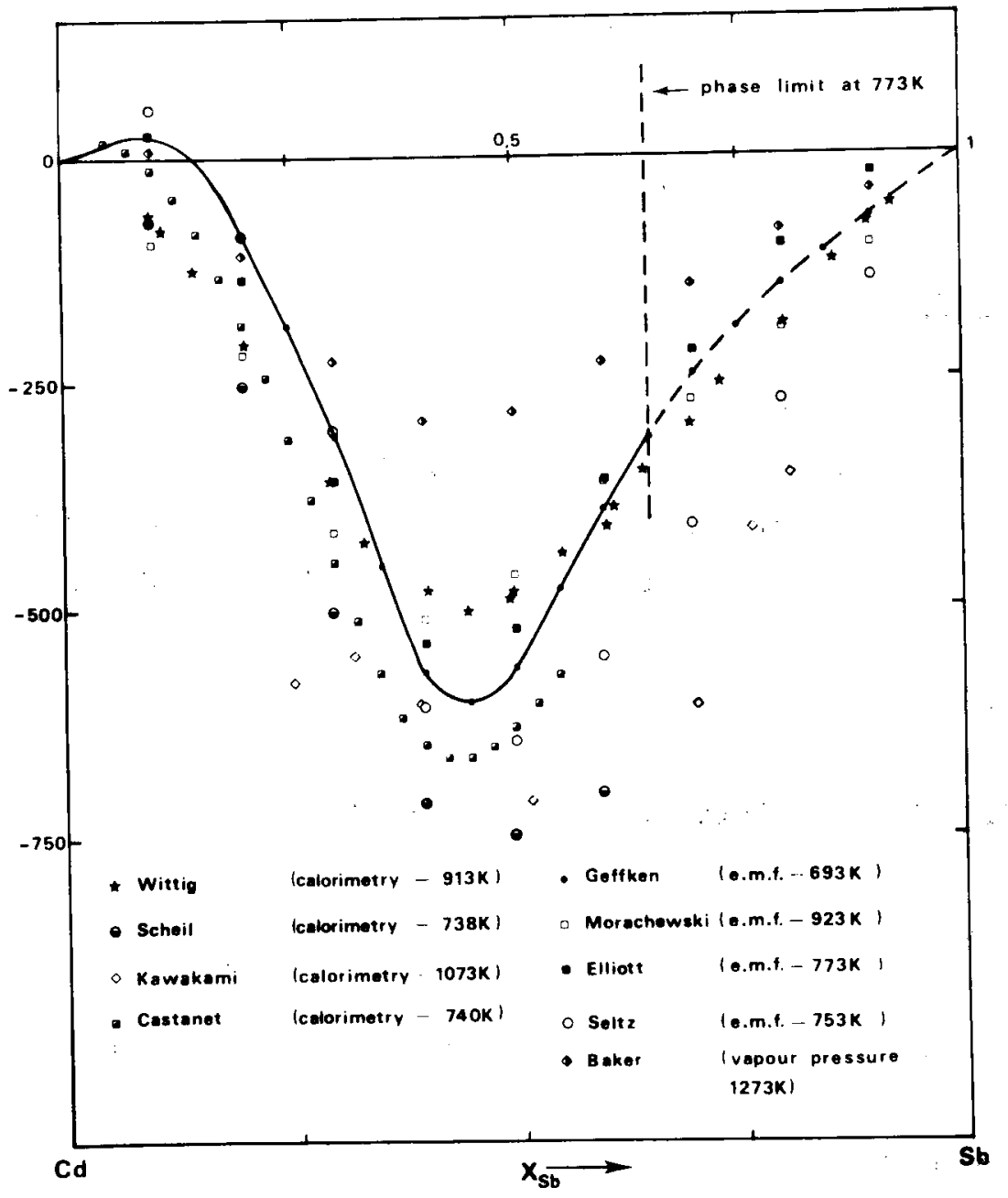

FIGURE 2

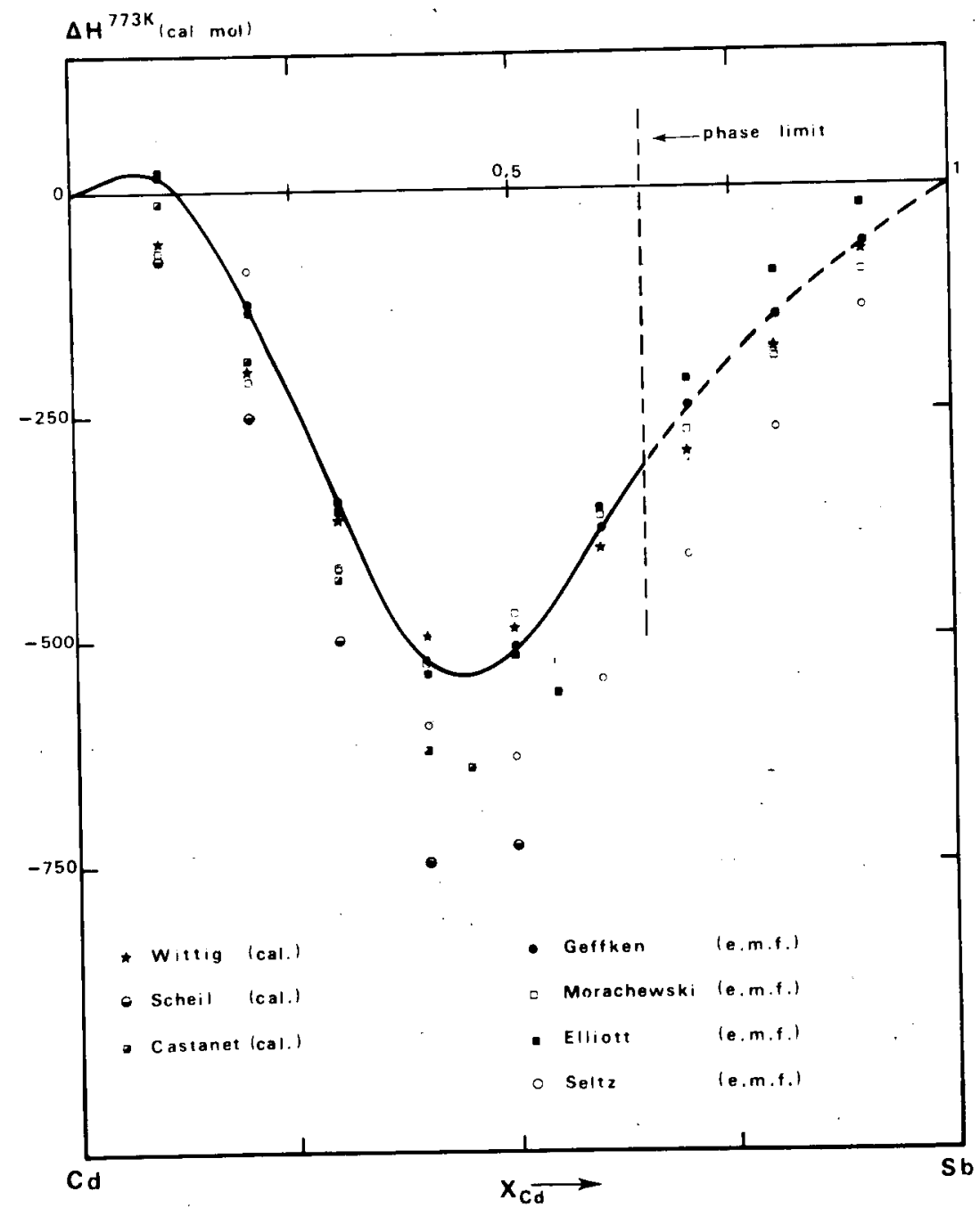




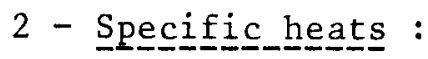

The specific heats of liquid alloys for different compositions have been measured by SCHICK. A numerical analysis has been achieved to present the results by step of 0.05 of $\mathrm{x}_{\mathrm{Cd}}$. The description of the analysis and the comparisor between calculated and experimental values are given respectively in appendix II and table I. As an excellent agreement is obtained, the calculated values have been used in the assesment.

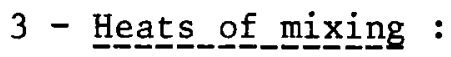

The heats of mixing measured at different temperatures and by different techniques are plotted in figure 2. In order to compare them, a correction using the $C_{p}$ values was made and the calculated values at $773 \mathrm{~K}$ are shown in figure 3. The selected values, which are listed in table II, agree within $+75 \mathrm{cal} / \mathrm{mol}$. compared to those of GEFFKEN, MORACHEWSKI, and WITTIG. Deviations of about 50 to 200 cal. in the composition range $0.35<\mathrm{x}_{\mathrm{Cd}}<0.8$ observed with SELTZ, SCHEI and CASTANET's values. BAKER's measurements are less negative by $300 \mathrm{cal}$. than the average calorimetric values where a; KAMAKAMI 's measurements are more negative by $300 \mathrm{cal} .(\Delta \mathrm{H}=-781$ and - $829 \mathrm{cal} / \mathrm{mol}$ respectively for $\mathrm{x}_{C d}=0.35$ and 0.533 ) than the average calorimetric measurements. These measurements have been disregarded in the present comparison.

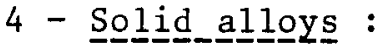

The selected values for the thermodynamic properties of formation of the solid compound $\mathrm{Cd}_{0.5} \mathrm{Sb}_{0.5}$ referred to solid cadmium and antimony are compared in the following table :

$$
\mathrm{T}(\mathrm{K}) \quad \Delta \mathrm{H}^{\mathrm{T}}(\mathrm{cal} / \mathrm{mol}) \quad \Delta \mathrm{S}^{\mathrm{T}}(\mathrm{cal} / \mathrm{mol}, \mathrm{K})
$$

\begin{tabular}{|c|c|c|c|}
\hline SELTZ & 687 & -1625 & -0.335 \\
\hline OLANDER & 538 & -1860 & -0.74 \\
\hline \multirow[t]{2}{*}{ BORG } & 298 & $-1641 \pm 125$ & $-0.3 \pm 0.25$ \\
\hline & 600 & $-1581 \pm 125$ & $-0.16 \pm 0.25$ \\
\hline SILVESTRI & 594.18 & -3337 & -3.09 \\
\hline EVSEEVA & 594.18 & 385 & 3.74 \\
\hline BILTZ & 298 & -1500 & - \\
\hline \multirow[t]{2}{*}{ SELECTED VALUES } & $\int 729$ & -1630 & -0.28 \\
\hline & 298 & -1594 & $-0.20 \quad \Delta \mathrm{C}_{\mathrm{p}} \simeq 0 \quad(\mathrm{cal} / \mathrm{mol} . \mathrm{K})$ \\
\hline
\end{tabular}


6.

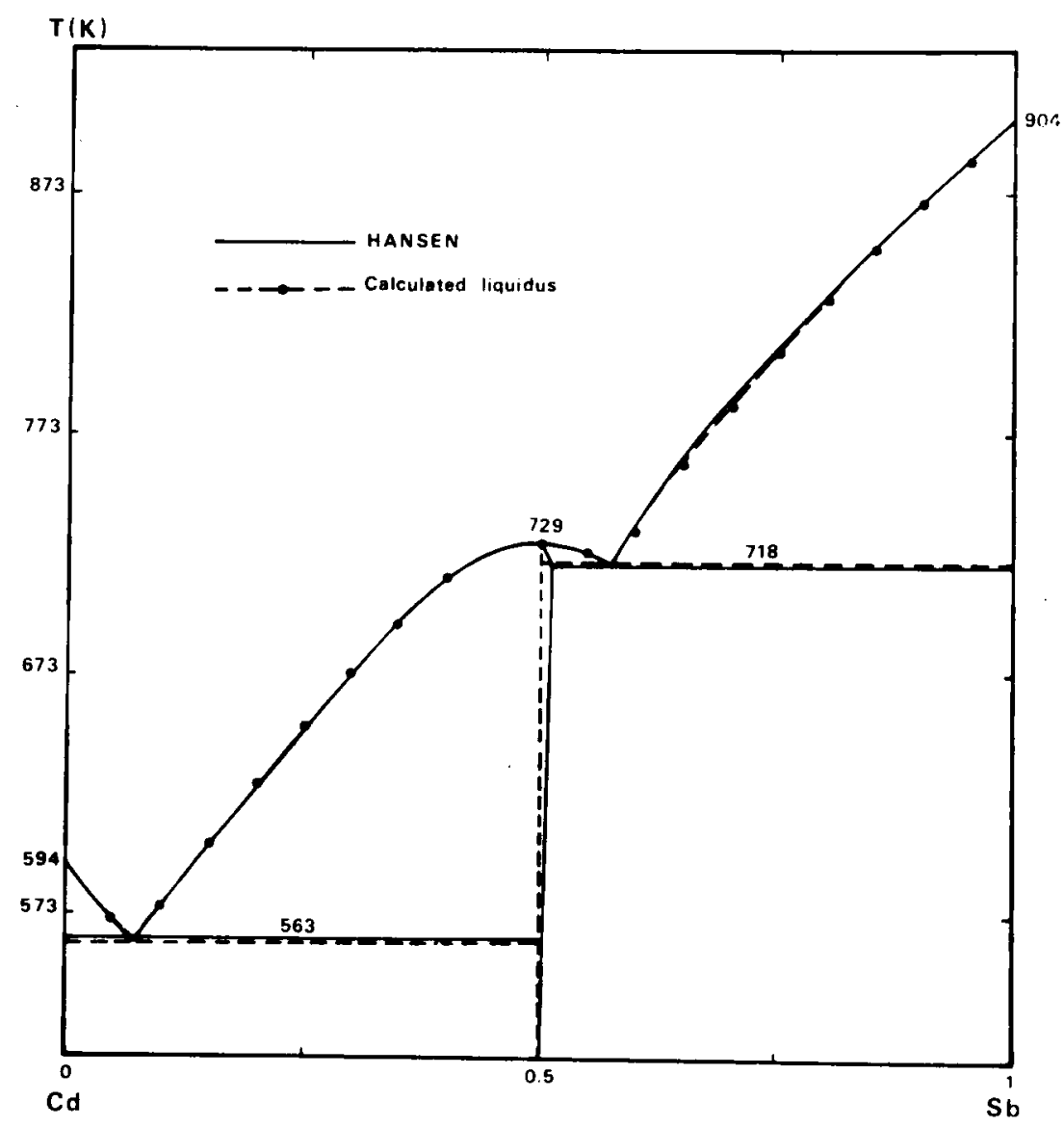

FIGURE 4 
The selected values agree well with SELTZ and BORG's measurements in the considered temperature range.

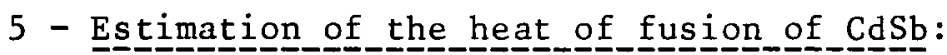

The heat of fusion of $\mathrm{Cd}_{0.5} \mathrm{Sb}_{0.5}$ has been measured by KUBASCHEWSKI who reports a value of $3830 \mathrm{cal} / \mathrm{mol}$, and by SELTZ who derived a value of 4135 from his e.m.f. measurements. From the selected values and considering the following equation :

$$
\left[\mathrm{L}_{\langle\mathrm{CdSb}\rangle}=\Delta \mathrm{H}_{(\mathrm{CdSb})}-\Delta_{\langle\mathrm{CdSb}\rangle}+0.5 \mathrm{~L}_{\mathrm{Cd}}+0.5 \mathrm{~L}_{\mathrm{Sb}}\right]_{\mathrm{TdSb}}
$$

a value of $4160 \mathrm{cal} / \mathrm{mol}$ is obtained.

Another alternative is to calculate the heat of fusion from the following equation ${ }^{(23)}$ :

$$
\mathrm{L}_{\mathrm{CdSb}}=-\mathrm{RT}_{\mathrm{CdSb}}^{2} \frac{\mathrm{d}_{!} \mathrm{ln}_{\mathrm{I} b}}{\mathrm{dx}_{\mathrm{Sb}}} /\left(0.5 \frac{\mathrm{d}^{2} \mathrm{~T}}{\mathrm{dx}_{4 \mathrm{Sb}}^{2}}\right)
$$

where $\mathrm{d}^{2} \mathrm{~T} / \mathrm{dx_{((Sb)) } ^ { 2 }}$ is the second derivative of the equation representing the liquidus line in the vicinity of the composition of the compound. The calculated value is equal to $4255 \mathrm{cal} / \mathrm{mol}$.

The proposed value for the latent heat of fusion is $4160 \pm 150 \mathrm{cal} / \mathrm{mol}$.

From the selected values of the thermodynamic properties for the liquids alloys and the intermetallic compound, the equilibrium phase diagram has been calculated, according to the equation described in appendix III. The calculated values are in excellent agreement with the diagram published in HANSEN's compilation as shown in figure 4. It can be observed that a very similar phase diagram is obtained if the specific heat contribution is neglected. 
<i> solid element or "stoechiometric" compound i

(i) liquid element i

$\ll i \gg$ compound $i$ in the solid alloy

((i)) compound $i$ in the liquid alloy

$\mathrm{T}_{\mathrm{i}}$ melting point of element or compound $\mathrm{i}$

$L_{i}$ latent heat of fusion of element or compound $i$

$\bar{C}_{p(i)}$ partial specific heat of component $i$ in the liquid phase

$\mathrm{C}_{\mathrm{p}<\mathrm{i}>}^{\circ}$ or $\mathrm{C}_{\mathrm{p}(\mathrm{i})}^{\circ}$ specific heat of pure component $\mathrm{i}$ in the corresponding state

$\Delta \overline{\mathrm{C}}_{\mathrm{p}(\mathrm{i})}=\overline{\mathrm{C}}_{\mathrm{p}(\mathrm{i})}-\mathrm{C}_{\mathrm{p}(\mathrm{i})}^{\circ}$

$\mathrm{C}_{\mathrm{p}}^{1}$ specific heat of the liquid alloy

$\Delta C_{p}^{1}=C_{p}^{1}-x_{((i))} \bar{C}_{p((i))}-\left(1-x_{i}\right) \bar{C}_{p((j))}$

$\Delta \overline{\mathrm{H}}_{((i))}, \Delta \overline{\mathrm{S}}_{((i))}$, partial heat and entropy of mixing of compound $i$ referred to the same state

$\Delta \mathrm{H}_{\langle i\rangle}, \Delta \mathrm{S}_{\langle i>}$ heat and enlropy of formation of solid $\mathrm{i}$ from the solid element T equilibrium temperature. 


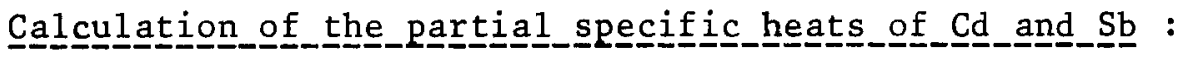

From the experimental values of $\mathrm{C}_{\mathrm{p}}$ measured by SCHICK presented in the form of $\left(\mathrm{C}_{\mathrm{P}}^{1}=\mathrm{aT}+\mathrm{b}\right)_{\mathrm{x}_{\mathrm{Cd}}},\left(\overline{\mathrm{C}}_{\mathrm{p}_{((\mathrm{Cd}))}}\right)_{\mathrm{T}}, \mathrm{x}_{\mathrm{Cd}}$ was obtained by a graphical method.

Using SCHICK's value of $\mathrm{C}^{\circ} \mathrm{p}(\mathrm{Cd})$ for pure liquid cadmium, $\left(\Delta \overline{\mathrm{C}}_{\left.\mathrm{P}_{((\mathrm{Cd}))}\right)}\right) \mathrm{T}_{\mathrm{Cd}}$ was calculated. The next steps were to calculate $\left(\Delta \overline{\mathrm{C}}_{\mathrm{p}_{((\mathrm{Cd}))}}=\mathrm{a}^{\prime} \mathrm{T}+\mathrm{b}^{\prime}\right) \mathrm{x}_{\mathrm{Cd}}$. the coefficients $\mathrm{a}^{\prime}$ and $\mathrm{b}^{\prime}$ being obtained by a least square $f_{i t}$. Integration of the GIBBS-DUHEM equation leads to $\left(\Delta \overline{\mathrm{C}}_{\left.\mathrm{P}_{((\mathrm{Sb}))}\right)}{ }^{\mathrm{x}_{\mathrm{Cd}}} \cdot\right.$

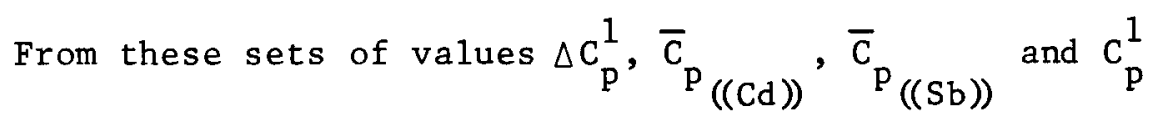

were calculated.

For different temperatures, the calculated values are compared with the experimental ones in table I. As an excellent agreement is obtained, the calculated values are used in the assesment. Table III presents the equations of $\bar{C}_{P_{((C d))}}, \bar{C}_{P_{((S b))}}$ and $C_{p}^{1}$. 


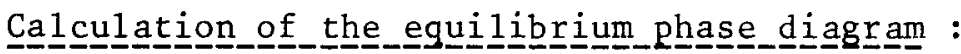

The liquidus representing the equilibrium between the liqui solution and a pure element $i$ is given by the following equation :

$$
\left[\mathrm{T}=\left(\Delta \overline{\mathrm{H}}_{((\mathrm{i}))}+\mathrm{L}_{\mathrm{i}}\right) /\left(\Delta \overline{\mathrm{S}}_{((\mathrm{i}))}+\mathrm{L}_{\mathrm{i}} / \mathrm{T}_{\mathrm{i}}\right)\right]_{\mathrm{T}}, \mathrm{x}_{\mathrm{i}}
$$

whereas, the liquidus representing the equilibrium between the liquid soluti and the intermetallic compound $\mathrm{CdSb}$ is given by :

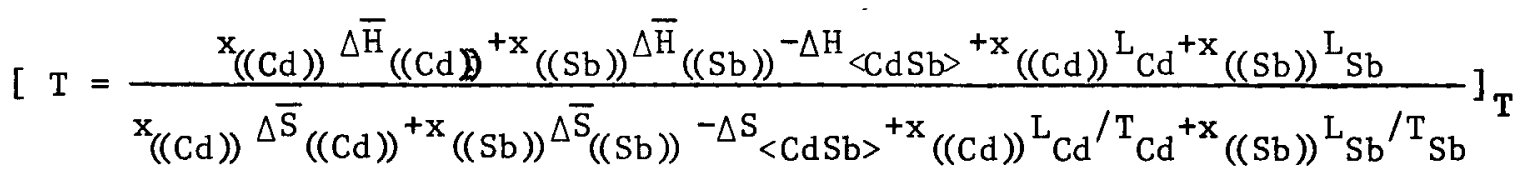

where

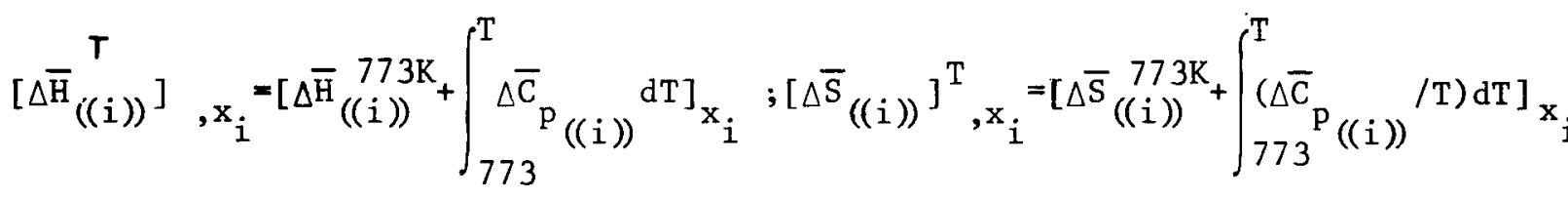

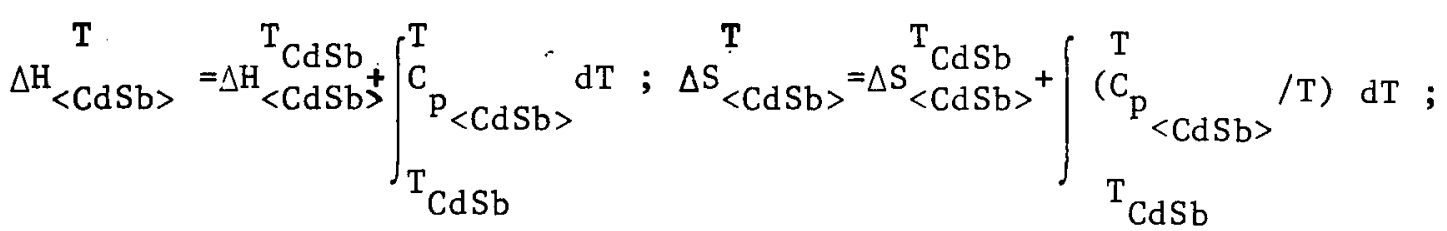

$\mathrm{L}_{i}^{T}=\mathrm{L}_{i}^{\mathrm{T}}+\int_{\mathrm{T}_{i}<i>}^{\mathrm{T}} \mathrm{C}_{\mathrm{p}} \mathrm{dT}-\int_{\mathrm{T}_{i}}^{\mathrm{T}} \mathrm{C}_{\mathrm{i}} \mathrm{dT}$

The liquidus has been calculated using the data listed in tables II. The specific heats of the undercoded liquids have been obtained by use of the equations given in table III. 
TABLE I

COMPARISON BETWEEN EXPERIMENTAL AND CALCULATED VALUES

OF THE SPECIFIC HEATS FOR Cd-Sb LIQUID ALLOYS

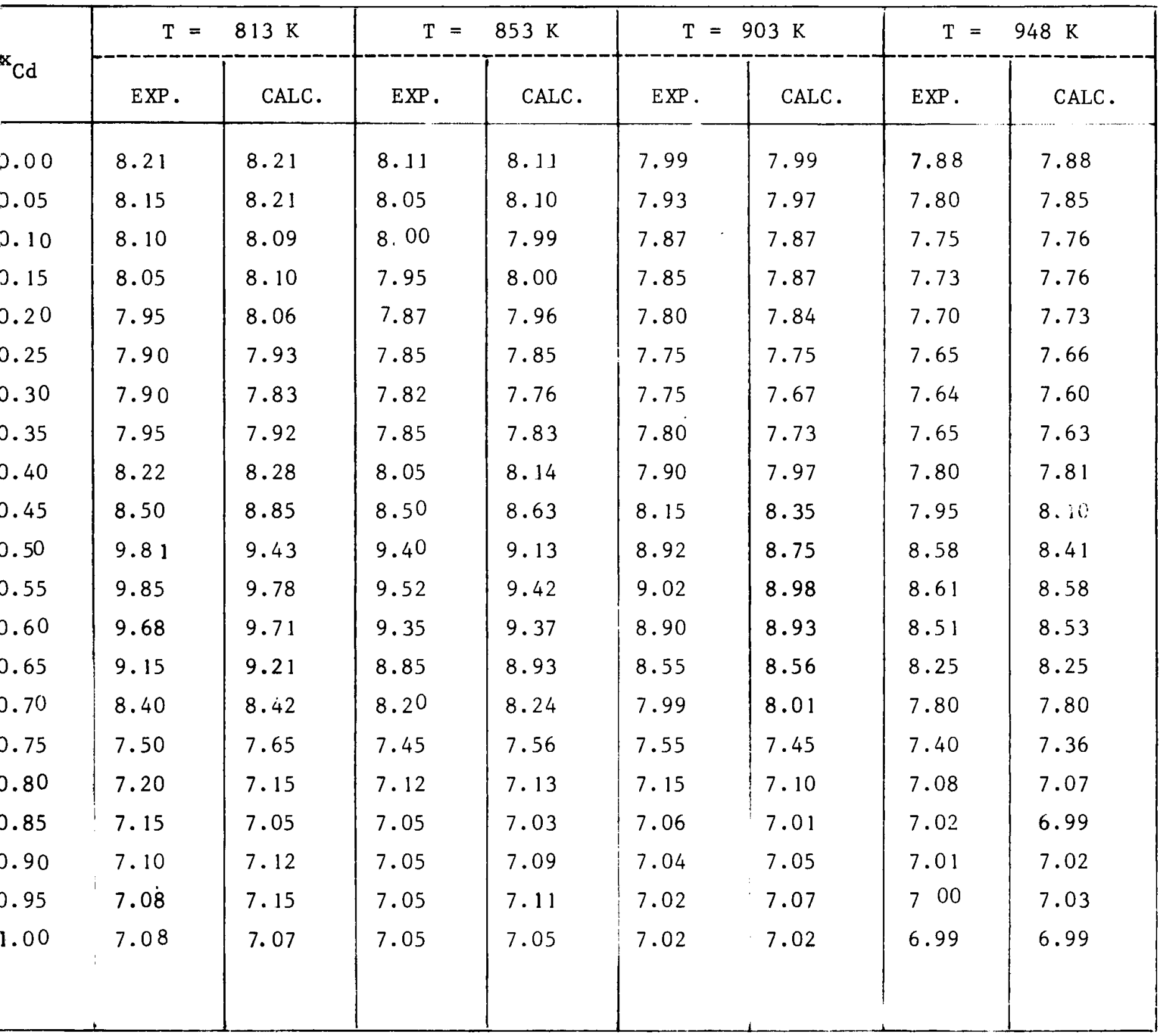




\section{TABLE II}

THERMODYNAMIC PROPERTIES FOR LIQUID ALLOYS AT $773 \mathrm{~K}$

REFERRED TO THE PURE LIQUID ELEMENTS

$$
\begin{aligned}
& { }^{\mathrm{Cd}}(\mathrm{Cd})+\mathrm{x}_{\mathrm{Sb}}(\mathrm{Sb}) \rightarrow \mathrm{Cd}_{\mathrm{x}_{\mathrm{Cd}}} \\
& -1-1,1-1
\end{aligned}
$$

${ }^{\mathrm{x}} \mathrm{Sb}$

$\Delta \overline{\mathrm{H}}_{\mathrm{Sb}}(\mathrm{cal} / \mathrm{mol})$

$\Delta \overrightarrow{\mathrm{S}}_{\mathrm{Sb}}^{\mathrm{xs}}(\mathrm{cal} / \mathrm{mol} \cdot \mathrm{K})$

$\Delta \overline{\mathrm{H}}_{\mathrm{Cd}}(\mathrm{cal} / \mathrm{mol})$

$\Delta \overrightarrow{\mathrm{s}}_{\mathrm{Cd}}^{\mathrm{xs}}(\mathrm{cal} / \mathrm{mol}$

0.00

1224.1416

5.1645

3.6000

0.0

0.0000

185.1425

2.2863

26.0

0.0393

- 638.8568

1.2136

92.0

0.1450

- 1260.8566

0.4090

0.20

- 1666.4815

180.0

0.2972

- 1894.1060

$-0.1573$

- 1897.7740

265.0

0.4666

$-0.4367$

330.0

0.6295

- 1693.5210

$-0.4719$

230.0

0.7335

- 1131.1303

$-0.1534$

- 110.0

0.7480

- 404.2504

0.4364

0.5523

- $\quad 18.4490$

0.6408

0.5969

144.5735

0.4723

0.3539

167.3693

0.2236

45.1844

0.1078

16.4358

0.0496

4.9389

0.0165

1.4679

0.0009

0.3254

$-0.0014$

0.000

0.0000

- 650.0

0.1164

- 1000.0

$-0.0625$

- 1180.0

$-0.0116$

- 1250.0

0.1578

- 1200.0

0.3555

- 1070.0

0.6274

- 910.0

0.9314

1.1291

1.2843

855.0
$-\quad 730.0$

1.3910

- 730.0

1.4137

1.00

$\S$ : phase boundary. For $\mathrm{x}_{\mathrm{Sb}}>0.65$, the data correspond to supercooled alloys.

$$
\begin{aligned}
& \text { Melting point : (K) } \\
& \mathrm{T}_{\mathrm{Cd}}=594.18 \\
& \mathrm{~T}_{\mathrm{Sb}}=904 \\
& \text { Heat of fusion : (cal/mol) } \\
& {\left[\Delta \overrightarrow{\mathrm{H}}_{\mathrm{Cd}} /\left(1-\mathrm{x}_{\mathrm{Cd}}\right)^{2}\right]_{\mathrm{x}_{\mathrm{Cd}} \rightarrow 1}=11400.0} \\
& \mathrm{~L}_{\mathrm{Cd}}=1480 \pm 20 \quad \mathrm{~L}_{\mathrm{Cd}}=4700 \pm 150 \\
& {\left[\Delta \overline{\mathrm{S}}_{\mathrm{Cd}}^{\mathrm{xs}} /\left(1-\mathrm{x}_{\mathrm{Cd}}\right)^{2}\right] \mathrm{x}_{\mathrm{Cd} \rightarrow 1}=17.0}
\end{aligned}
$$




$$
\text { a. } 10^{3}
$$

0.00

0.05

0.10

0.15

0.20

0.25

0.30

0.35

0.40

0.45

0.50

0.55

0.60

0.65

0.70

0.75

0.80

0.85

0.90

0.95

1.00
$-0.65526$

5.41558

$-3.07776$

$-3.26298$

2.42711

4.86587

$-2.44533$

$-0.63200$

$-13.73276$

$-0.63200$

$-24.76938$

$-29.66838$

$-0.63200$

$\left\{\begin{array}{r}-25.65938 \\ -0.63200\end{array}\right.$

$-14.65567$

$-0.63200$

$-1.58279$

8.16422

$-0.63200$

11.32622

$-0.63200$

8.27929

2. 62552

$-1.19552$

$-1.26574$

$-0.84881$

$-0.63200$ b

11.37703

1.95720

9.27624

9.90966

5.27124

3. 16813

8.37542

7.41900

18.25690

7.41900

27.50445

7.41900

31.63221

7.41900

28.34069

7.41900

19.17382

7.41900

8.22472

7.41900

0.01567

7.41900

$-2.69294$

7.41900

$-0.17759$

4.56787

7.81852

7.93349

7.59844

7.41900 $a^{\prime} \cdot 10^{3}$

-2.50000
-3.10055

$-2.37012$

$-2.41378$

$-3.61691$

$-4.28777$

$-1.72503$

$-2.50000$

4.08735

$-2.50000$

10.67695

$-2.50000$

14.20168

$-2.50000$

10.44204

$-2.50000$

$-11.82262$

$-2.50000$

$-19.45178$

$-2.50000$

$-36.05757$

$-2.50000$

$-41.96374$

$-2.50000$

$-33.65473$

$-14.04296$

3.50950

3.56274

$-1.77477$

$-10.62020$ $b^{\prime}$

9.56600

10.06000

9.42779

9.39630

10.37907

10.95967

8.92900

9.56000

4.14817

9.56000

$-1.37412$

9.56600

$-4.34477$

9.56600

$-1.25621$

9.56000

8.96235

9.56600

23.73414

9.56600

37.63447

9.56600

42.78438

9.56600

35.91961

19.45518

4.51197

4.07438

8.38283

15.71867 $a^{\prime \prime} \cdot 10^{3}$

$-2.50000$

$-2.67474$

$-2.44088$

$-2.54116$

$-2.40810$

$-2.04436$

$-1.94112$

$-1.94000$

$-2.14970$

$-1.84600$

$-3.50158$

$-1.75300$

$-5.53985$

$-1.65900$

$-7.60867$

$-1.56600$

$-13.38079$

$-1.47260$

$-8.73038$

$-1.37900$

$-7.31340$

$-1.28600$

$-4.66077$

$-1.19200$

$-2.20421$

$-6.70817$

$-0.48977$

$-0.78289$

$-0.89511$

$-0.63200$ $b^{\prime \prime}$

9.56000

9.65486

9.41263

9.47330

9. 35750

9.01178

8.76292

8.92200

9.08622

8.62300

10.17731

8.70700

11.84487

8.60000

13.54224

8.49250

14.57865

8.38500

14.42849

8.27800

13.18225

8. 17050

10.95025

8.06300

8.84671

7.54533

7.32254

7.54758

7.63766

7.41900
903.5-910

887-903

869-903

850-903

829-903

808-903

785-833

833-903

760-836

836-903

717-838

838-903

724-838

838-903

727-838

838-903

724-860

860-903

714-877

877-903

695-880

880-903

674-881

$881-903$

$651-903$

628-903

603-903

575-903

572-903

594-903

TABLE III

Partial and integral specific heats for liquid alloys. 


\section{BIBLLIOGRAPHY}

( 1) M. HANSEN and K. ANDERKO, "Constitution of binary alloys", McGraw Hill Book Co., N.Y., 1958

( 2) R.P. ELLIOTT, "Constitution of binary alloys", 2nd suppl., McGraw Hill Book Co., N.Y., 1965

( 3) F.A. SHUNK, "Constitution of binary sloys", 3rd suppl., McGraw Hill Book Co., N.Y., 1969

( 4) E. HAYER, private communication

( 5) H. SELTZ and J.C. deHAVEN, Trans. Met. Soc. AIME, 1935, 117, 218

( 6) A. OLANDER, Z. Physik. Chem., 1935, 173, 284

( 7) R.J. BORG, Trans. Met. Soc. AIME, 1961, 221, 242

( 8) G.V. EVSEEVA, A.M. EVSEEV and L.V. ZENKEVICH, Vest. Mosk. Univ. Khim., $1969,24,6,29$

( 9) V.J. SILVESTRI, J. Phys. Chem., 1960, 64, 826

(10) G. SCHICK, Ph.D Thesis, N.Y. Univ., 1971, n71-29,691

G. SCHICK and K. KOMAREK, Z. Met a $11 \mathrm{kde}, 1974,65,2,112$.

(11) 0. KUBASCHEWSKI, Z, Elekt rochem., , 1941,47, 475

(12) W. EILTZ and C. HAASE, Z. Anorg. Chem., 1923, 129, 141

(13) M. KAWAKAMI, Sci. Pept. Res. Inst. Tohoku. Univ., A, 1930, 19, 521

(14) F.E. WITTIG and E. GEHRING, Ber. Bunsenges., 1966, 70, 717

(15) E. SCHEIL and H.L. LUKAS, Z. Metallkde., 1961, 52, 417

(16) R. CASTANET, private communication

(17) R. GEFFKEN, K.L. KOMAREK and E. MILLER, Trans. Met. Soc. AIME, 1967, 239, 8,1151

(18) L.N. GERASIMENKO, I.V. KIRICHENKO, L.N. LOZHKIN and A.G. MORACHEWSKII, Akad. Nauk SSSR, Otd. Obsch. i Tekhn. Khim., 1965, 236

(19) J.F. ELLIOTT and J.C. CHIPMAN, Trans. Far. Soc., 1953, 47, 138

(20) H. SELTZ and B.J. deWITT, J. Amer. Chem. Soc., 1938, 60, 1305

(21) E. SCHEIL and H. BAACH, Z. Metallkde, 1959, 50, 7, 386

(22) E.H. BAKER, Trans. Inst. Min. Met., 1969, 78, 83

(23) I.ANSARA, F.DURAND, P.DESRE et E.BONNIER, Bul1. Soc. Chim., 1966, 4, 1935.

(24) R. HULTGREN et al., "Selected Values of the Thermodynamic Properties of the Elements", 1973, American Society for Metals, Metals Park, Ohio, USA. 
Imprimeur : Ecole Nationale Supérieure d'Electrochimie et d'Electrométallurgie Domaine Universitaire

38 - SAINT MARTIN D'HERES 